\title{
Attomole-level Genomics with Single-molecule Direct DNA, cDNA and RNA Sequencing Technologies
}

\author{
Fatih Ozsolak \\ Helicos BioSciences Corporation Cambridge, MA, USA \\ fatihozsolak@gmail.com
}

http://dx.doi.org/10.21775/cimb.018.043

\begin{abstract}
With the introduction of next-generation sequencing (NGS) technologies in 2005, the domination of microarrays in genomics quickly came to an end due to NGS's superior technical performance and cost advantages. By enabling genetic analysis capabilities that were not possible previously, NGS technologies have started to play an integral role in all areas of biomedical research. This chapter outlines the low-quantity DNA/ cDNA sequencing capabilities and applications developed with the Helicos single molecule DNA sequencing technology.
\end{abstract}

\section{Introduction}

The era of first generation sequencing dominated by Sanger sequencing (Sanger and Coulson, 1975) came to an end with the introduction of the Roche/454 platform (Margulies et al., 2005) in 2005, followed by the Solexa/ Illumina system (Bentley et al., 2008) in 2006 and the Applied Biosystems SOLiD system (Valouev et al., 2008) in 2007. These second generation sequencing (SGS) technologies have enjoyed a warm welcome from the scientific community. With such an enthusiastic customer base and investments from the users and SGS companies in technology and applications development, many novel capabilities have been achieved within a very short timeframe after their launch. SGS applications in biomedicine have primarily been whole/targeted genome sequencing, digital gene expression, DNA methylation sequencing and copy-number variation. However, SGS technologies have expanded to chromatin immunoprecipitation sequencing (ChIP-seq), RNA immunoprecipitation sequencing, whole transcriptome analyses, single cell analyses, nucleic acid structure determination, chromatin conformation analysis and many others (Mardis, 2008; Morozova and Marra, 2008). SGS technologies have also been adapted beyond nucleic acid sequencing and, for instance, to protein-DNA affinity measurements (Nutiu et al., 2011), which may find frequent use in bio-medicine in the future. In this chapter, the Single Molecule DNA/cDNA Sequencing (SMDS) and Direct RNA Sequencing (DRS) technologies developed and commercialized by Helicos BioSciences Corporation are outlined. Detailed procedures for the application of SMDS for low-quantity/attomole-level DNA/cDNA sequencing applications, such as for ChIP-seq (Goren et al., 2010) or circulating cell-free blood nucleic acids (van den Oever et al., 2012), are also provided.
Single molecule DNA/cDNA sequencing (SMDS) and direct RNA sequencing (DRS) technologies

The first single molecule second- (or third-, depending on the criteria used) generation sequencer was commercialized by Helicos Bio-Sciences Corporation (Cambridge, MA, USA) in 2007 (Harris et al., 2008). The system integrates recent advances in automated single molecule fluorescent imaging, fluidics technologies and enzymology, and enables SMDS and DRS capabilities. The system is the first and currently the only system that can sequence RNA directly (e.g. without cDNA synthesis) in addition to DNA and cDNA molecules (Ozsolak et al., 2009). The system proved its value by enabling discovery of novel classes of short RNAs (Kapranov et al., 2010), genome-wide quantitative mapping of polyadenylation sites (Ozsolak et al., 2010a), characterization of circulating tumour cells (Yu et al., 2012), detecting fetal genetic abnormalities by sequencing maternal plasma DNA (van den Oever et al., 2012), ancient DNA sequencing (Orlando et al., 2011) and many other biological and technical advances and discoveries. The SMDS and DRS chemistry and operating principles have been described in detail previously in multiple publications (Harris et al., 2008; Ozsolak, 2012; Ozsolak and Milos, 2011). Below is a brief summary from the previous presentations of this technology.

The sequencing system consists of two main components (Harris et al., 2008; Ozsolak, 2012): (i) flow cells, which create an environment for template nucleic acid attachment, sequencing chemistry steps and single molecule fluorescence imaging, and (ii) the HeliScope ${ }^{\mathrm{TM}}$ sequencer, which is an integrated fluidics, optics (for automated, fast and high-throughput imaging) and image/ data analysis system for introduction of sequencing reagent formulations to the flow cells, taking single molecule images and analysing the images in real-time (e.g. during the sequencing run) to deduce read sequences. Sequencing flow cell surfaces are coated with poly(dT) oligonucleotides covalently attached at their $5^{\prime}$ amine ends to an epoxide-coated ultra-clean glass surface. These oligonucleotides serve two purposes: (i) to capture the $3^{\prime}$ poly(A)-tail containing nucleic acids onto surfaces by hybridization, and (ii) to prime and initiate the sequencing steps. The current requirement for nucleic acid sample preparation for this platform is the presence of a $3^{\prime}$ poly $(A)$ tail >25-30 nucleotide (nt) in length and 'blocked' at its $3^{\prime}$ end against extension by the polymerase used in the sequencing-by-synthesis steps. $3^{\prime}$ polyadenylation and blocking of DNA/cDNA templates is performed using terminal transferase with dATP and dideoxyATP, respectively. $E$. coli or yeast poly $(A)$ polymerases with ATP and 3'deoxyATP are used for RNA 3' poly(A)-tail addition and blocking. However, for the characterization of RNA species that naturally contain a poly $(A)$ tail for the purposes of gene expression measurements, polyadenylation site 
mapping and other applications, such poly(A)-tail addition is not required and direct hybridization of poly $(A)+$ RNAs to surfaces can be performed. It is also possible to change the poly $(\mathrm{dT})$ oligonucleotides on the surface to other nucleotides for the capture and sequencing of other targets (for instance, for targeted selection and sequencing of particular DNAs/RNAs of interest in a single step manner) (Thompson et al., 2012).

After hybridization of templates to the poly(dT) surface primers, to begin sequencing at the unique template region adjacent to the poly(A)-tail, each primer-template pair is 'filled' in with thymidine triphosphate by a polymerase, and then 'locked' in position with $A, C$ and $G$ Virtual TerminatorTM (VT) nucleotides. VTs (Bowers et al., 2009) are nucleotide analogues used for sequencing, containing a fluorescent dye as part of a chemically cleavable group that prevents the addition of another nucleotide. After washing away the excess, unincorporated nucleotides, the surface is irradiated with a laser at an angle that allows total internal reflection at the surface. In such a situation, an evanescent field is generated so that only molecules very close to the surface are excited by the laser. This reduces the background level of fluorescence such that single molecules can be detected. After image acquisition across desired number of positions per channel, the locations of templates on the surface are recorded. The liquid in each channel is replaced with a mixture that cleaves the fluorescent dye and virtual terminator group off the incorporated nucleotide, rendering the strands suitable for further VT incorporation. The sequencing-by-synthesis reaction consists of polymerase-driven cyclic addition of the VTs in the C, T, A and G order. Each VT addition is followed by a rinsing, imaging (to locate the templates that incorporated the particular VT), and cleavage cycle. Repeating this cycle many times provides a set of images from which the base incorporations are detected and then used to generate sequence information for each template molecule. The sequencing operation principles described above are common for both SMDS and DRS. However, the components and conditions of chemistry and reaction steps are different between the two. As a result, different sequencing kits are provided for DRS and SMDS, and, at this point, it is not possible to sequence DNA/cDNA and RNA molecules concurrently in a single sequencing run.

Each SMDS and DRS run is currently performed with 120 VT-incorporation cycles and contains up to 50 independent channels, producing up to 25 million aligned reads $\geq 25 \mathrm{nt}$ in length (up to $55 \mathrm{nt}$ in length, median $\sim 34$ nt) per channel depending on the user-defined run time (112days) and throughput (e.g. imaging quantity per channel). Longer reads can be achieved by doing more cycles of sequencing, although the quality and the yield/ efficiency of the sequencing reaction may decrease with longer runs. Error rates are in the range of $4-5 \%$, dominated by missing base errors $(\sim 2-3 \%)$, while insertion $(\sim 1 \%)$ and substitution $(\sim 0.4 \%)$ errors are lower.

The system's single molecule nature and low input DNA/RNA requirements (400-1000 amol) are particularly advantageous for settings with limited cell/nucleic acid quantities (Goren et al., 2010; Ozsolak et al., 2010b). Its avoidance of extensive manipulation steps (Figure 1) result in better coverage, minimal or no $\mathrm{GC}$ bias and higher quantification and representation range for DNA and RNA compared with other SGSs (Figure 2), even in ancient, formalin-fixed paraffin-embedded tissue (FFPET) and other highly degraded samples (Orlando et al., 2011). Helicose's DRS today is the only technology that can avoid wellknown reverse transcription and sample manipulation

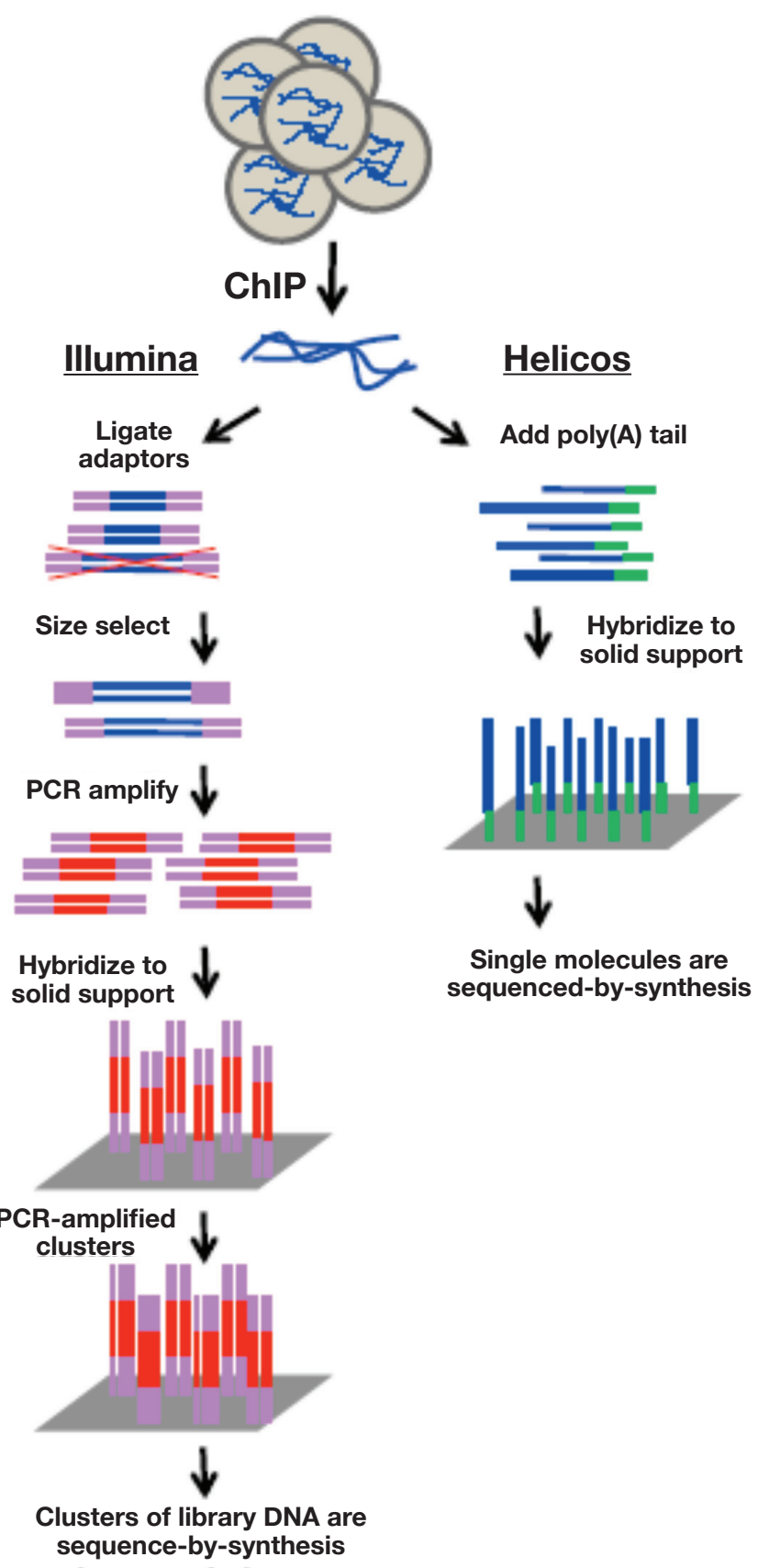

Figure 1. ChIP-seq sample preparation and sequencing steps with Illumina and Helicos SMDS technologies. Blue lines: original/unamplified ChIP DNA; green lines: poly(A) tails; pink lines: adaptors; red lines: amplified ChIP DNA; grey rectangles: sequencing flow cell surfaces. The figure was reprinted with permission from the Nature Publishing Group (Goren et al., 2010). 


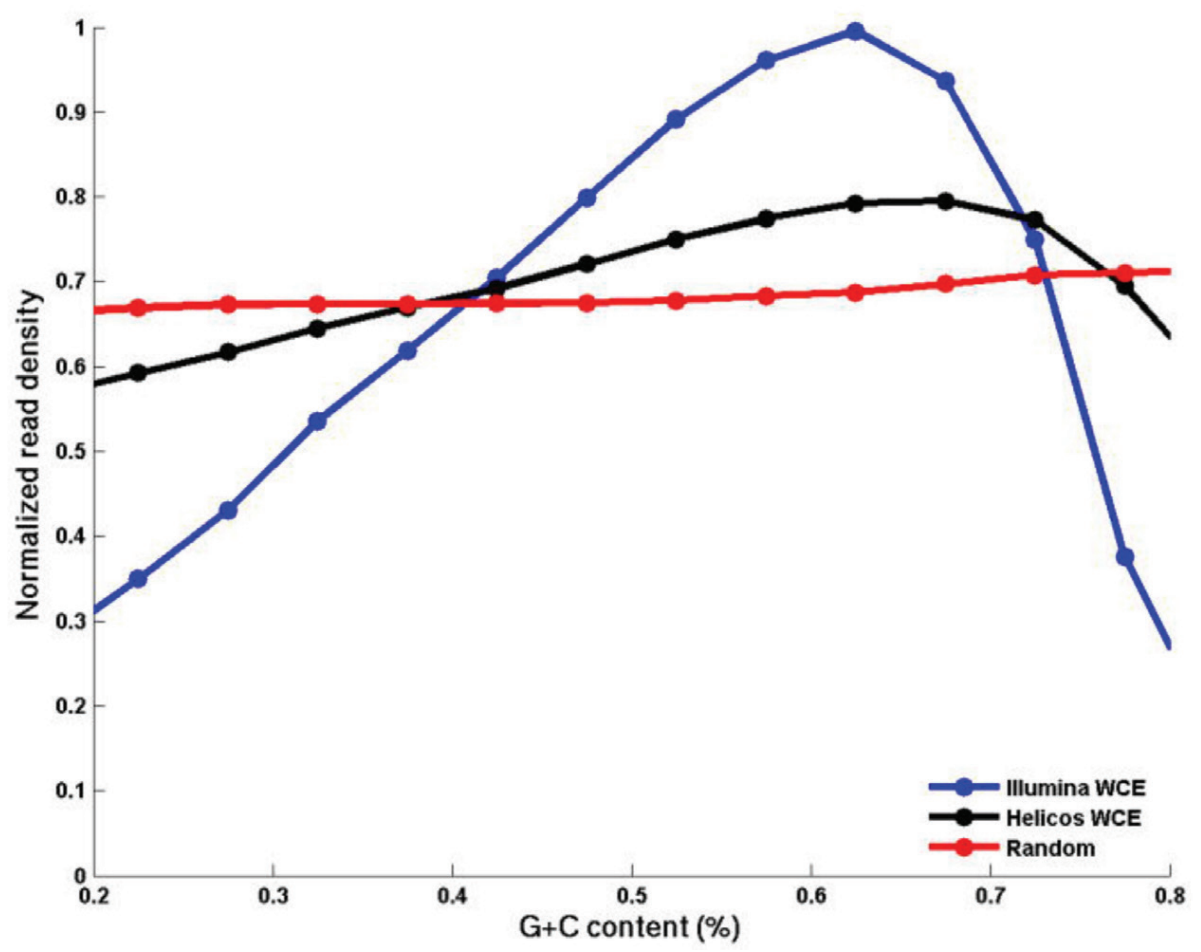

Figure 2. Sequencing bias comparison. Normalized read density obtained from un-enriched input control 'whole cell extract' (WCE) samples analysed by Illumina (blue) or Helicos (black) is plotted as a function of GC percentage for 100 bp windows. A theoretical 'expected' distribution obtained by computational simulation is shown in red (Random). The Helicos SMDS data show a relatively even distribution across $20-80 \%$ GC-content. The figure was reprinted with permission from the Nature Publishing Group (Goren et al., 2010).

biases for sequencing RNAs. One advantage of DRS is the universality of sample preparation steps for different applications. In other words, unlike RNA sequencing methods that require intermediate cDNA molecules and different cDNA synthesis and sample manipulation steps for short and long RNAs, DRS requires only 3' polyadenylated templates. Thus, both short and long RNAs can be sequenced together in a single experiment. The system's short read lengths, up to 55 nucleotides (nts), lack of paired read capability and error rate poses challenges in certain applications such as alternative splicing detection, microbiome sequencing and de novo genome sequencing. The system may be altered to enable elevated read lengths and paired reads in theory through minor modifications, but the errors may not be improved significantly. This is largely because the majority of the errors are caused by fluorescent dye blinking during the imaging step and there is no apparent remedy for this issue at present. The system is capable of single step target selection and sequencing (Thompson et al., 2012), which provides advantages in targeted sequencing and diagnostics applications focusing on gene sequencing. A modified version of the system has been extended to proteomics (Tessler et al., 2009).

\section{Materials}

For reagents used, see Table 1. For equipment used, see Table 2.

\section{Methods}

This protocol is for the preparation of low quantity DNA/ cDNA samples for SMDS genome re-sequencing, ChIPseq and other applications (Goren et al., 2010). For simplicity, the protocol assumes that the DNA/cDNA has been fragmented into a desired size range $>50$ nucleotides in length. Satisfactory fragmentation results have been obtained with DNA sheared by Covaris, Branson or Misonix sonicators. DNA should be free of RNA contamination. Extensive RNase digestion and clean up with a Reaction Cleanup Kit are highly recommended (Qiagen, catalogue no. 28204). DNA should be accurately quantitated prior to use. The Quant-iT ${ }^{\mathrm{TM}}$ PicoGreen dsDNA Reagent Kit with a Nanodrop 3300 Fluorospectrometer is strongly recommended, but standard plate readers may also be used.

Molecular biology-grade nuclease-free glycogen or linear acrylamide can be used as carrier during ChIP DNA clean-up/precipitation steps but carrier nucleic acids such as salmon sperm DNA should not be added prior to tailing.

\section{$\operatorname{Poly}(A)$ tailing reaction}

1 Add the following components in the indicated order: 2 $\mu \mathrm{l}$ of NEB terminal transferase $10 \times$ buffer, $2 \mu \mathrm{l} 2.5 \mathrm{mM}$ $\mathrm{CoCl}_{2}$, and $10.8 \mu \mathrm{l} \mathrm{DNA} / \mathrm{cDNA}$ in nuclease-free water.

2 Heat the above mix at $95^{\circ} \mathrm{C}$ for $5 \mathrm{~min}$ in a thermocycler for denaturation, followed by rapid cooling on a pre- 
Table 2.1 Reagents

\begin{tabular}{ll}
\hline Reagent & Recommended Vendor and Catalogue \# \\
\hline Terminal transferase kit & New England Biolabs M0315 \\
dATP & Roche 11277049001 \\
Biotin-ddATP & Perkin Elmer NEL548001 \\
Non-poly(A) CARRIER OLIGONUCLEOTIDE & IDT \\
Bovine serum albumin & NEB B9001S \\
Nuclease-free water & Ambion AM9932 \\
Quant-iTTM PicoGreen dsDNA reagent & Invitrogen P11495 \\
\hline
\end{tabular}

Table 2.2 Equipment

\begin{tabular}{ll}
\hline Equipment & Recommended Vendor and Model \\
\hline Thermal cycler & Bio-Rad DNA Engine Tetrad $\AA 2$ \\
Refrigerated microcentrifuge & Eppendorf 5810 R \\
Aluminium blocks & VWR 13259-260 \\
Nanodrop 3300 & Thermo Fisher Scientific \\
\hline
\end{tabular}

chilled aluminium block kept in an ice and water slurry $\left(\sim 0^{\circ} \mathrm{C}\right)$. It is essential to chill the block to $0^{\circ} \mathrm{C}$ in an ice/ water slurry and to cool the sample as quickly as possible to $0^{\circ} \mathrm{C}$ to minimize reannealing of the denatured DNA.

3 Mix the following reagents on ice and add to the 14.8 $\mu$ l denatured DNA from step 2, to a total volume of 20 $\mu \mathrm{l}$ for each sample: $1 \mu \mathrm{l}$ of NEB terminal transferase (diluted 4-fold to $5 \mathrm{U} / \mu \mathrm{l}$ using $1 \times$ NEB terminal transferase buffer), $4 \mu \mathrm{l}$ of $50 \mu \mathrm{M}$ dATP and $0.2 \mu$ l of NEB BSA.

4 Place the tubes in a thermocycler and incubate at $37^{\circ} \mathrm{C}$ for $1 \mathrm{~h}$, followed by $70^{\circ} \mathrm{C}$ for $10 \mathrm{~min}$ to inactivate the enzyme.

\section{3' End blocking reaction}

1 Denature the $20 \mu \mathrm{l}$ polyadenylation reaction from step 4 from 'poly $(A)$ tailing reaction' above at $95^{\circ} \mathrm{C}$ for $5 \mathrm{~min}$ in a thermocycler, followed by rapid cooling on a prechilled aluminium block kept in an ice/water slurry ( $\left.0^{\circ} \mathrm{C}\right)$.

2 For each sample, add the following blocking mastermix to the denatured DNA from step 1, to a total volume of $30 \mu \mathrm{l}: 1 \mu \mathrm{l}$ NEB terminal transferase $10 \times$ buffer, $1 \mu \mathrm{l} 2.5$ $\mathrm{mM} \mathrm{CoCl} 2,1 \mu \mathrm{l}$ NEB terminal transferase (diluted 4fold to $5 \mathrm{U} / \mu \mathrm{l}$ using $1 \times \mathrm{NEB}$ terminal transferase buffer), $0.5 \mu \mathrm{l} 200 \mu \mathrm{M}$ Biotin-ddATP, and $6.5 \mu \mathrm{l}$ nuclease-free water.

3 Place the tubes in a thermocycler and incubate at $37^{\circ} \mathrm{C}$ for $1 \mathrm{~h}$, followed by $70^{\circ} \mathrm{C}$ for $20 \mathrm{~min}$.

4 Add 2 pmol of the carrier oligonucleotide to the heatinactivated $30 \mu \mathrm{l}$ terminal transferase reaction from step 3. At this point, the sample may be stored at $-20^{\circ} \mathrm{C}$ or below for future use or hybridized to a sequencing flow cell directly. The carrier oligonucleotide is added to the sample after the completion of the poly $(\mathrm{A})$ tailing and 3 ' blocking steps to minimize template loss during the sample loading steps. It does not contain a poly $(A)$ tail and therefore does not hybridize to flow cell surfaces. The sequence and length (preferably 50 80 mer) of the oligonucleotide can be chosen by the user with the only sequence constraint being that it should not interfere with a poly(A):poly-T hybridization. 3 " blocking is preferred to ensure that the polyA tail is not sequenced. The sequence 5'-TCACTATTGTTGA GAACGTTGGCCTATAGTGAGTCGTATTACGCGCGG T[ddC]-3' has been used successfully as the Carrier Oligonucleotide but many others can be used.

Flow cell hybridization and SMDS

The detailed procedures for sample loader usage, flow cell rehydration, sample hybridization buffer, fill and lock steps, software and sequencer usage are regularly updated and the latest versions should be obtained from the manufacturer. This section is intended to describe several relevant details for the purposes of SMDS.

Hybridization of samples to flow cell channels is performed in 7-100 $\mu \mathrm{l}$ volume. The samples are mixed 50:50 with 2 hybridization buffer provided in the SMDS Kit. In general, $0.5-2 \mathrm{fmol}$ of DNA/cDNA material is required to optimally load each sequencing channel, although lower quantities can be used for less than optimal aligned read yields per channel. Following hybridization, the template molecules are filled and locked and the flow cells are moved to the HeliScope. The manufacturer-supplied sequencing scripts offer the user the opportunity to run one or two flow cells per run, to define the desired number and location of channels to be sequenced, and to request the desired imaging quantity (e.g. throughput) per channel (the system currently allows up to 1400 fields of view per 
channel, with up to 25 million aligned reads $\geq 25 \mathrm{nt}$ in length per channel).

\section{Data analysis}

The various programs and pipelines for the filtering, alignment and downstream analyses of the data, and the corresponding user manuals can be downloaded freely at http://open.helicosbio. com. Briefly, an initial filtering step is performed on the raw reads before initiating their alignment to reference sequences. This filtering step involves the following read selection steps:

1 SMDS generates reads between $6 \mathrm{nts}$ and $55 \mathrm{nts}$ in length. Depending on the experimental goals, the reference sequence complexity and size, a userdefined minimum read length cut off is employed to remove short reads that cannot be aligned reliably to save computing time and power. $\geq 25 \mathrm{nt}$ cut-off is routinely used for alignment to human and mouse genomes. However, for smaller and less-complex genomes, reads as short as $15 \mathrm{nt}$ can be used.

2 Any $5^{\prime}$ poly $T^{\top}$ stretches in the reads are trimmed. The likely cause of such T 3 homopolymeric stretches is incomplete fill with dTTP, leading to sequencing initiation within the poly(A) tail. Therefore, $5^{\prime}$ poly-T trimming is preferred to minimize potential misalignment events.

3 Because of flow cell surface imaging errors, artificial reads that have a repetition of the VT-addition order sequence (CTAG) may appear. Such reads are eliminated during the filtering step.

Given that the majority of sequencing errors are due to indels, an aligner that is tolerant to these types of errors should be employed. We highly recommend the use of the indexDPgenomic aligner (Giladi et al., 2010) and downstream data analysis, genotyping and quantification tools freely available at http://open.helicosbio.com. While multiple aligners are available and can align SMDS reads, including Mosaik (http://code. google.com/p/mosaikaligner/) and SHRiMP (Rumble et al., 2009), the use of these aligners may result in a reduction in actual aligned reads due to their reduced ability to deal effectively with indels.

\section{SMDS ChIP-seq and other application notes}

The most robust performance with this protocol and SMDS is generally obtained with 6-9 ng of DNA with an average size of 400-500 nucleotides but $1 \mathrm{ng}$ or less can be used successfully. This protocol has been successfully used for sequencing of fetal DNA from 200-300pg of maternal cellfree blood nucleic acids (van den Oever et al., 2012). Because sequencing efficiency depends on the number of free $3^{\prime}$ hydroxyls that can be tailed, molarity must be estimated for optimal performance. If the average DNA size is shorter, correspondingly less mass of DNA should be used. If more than $18 \mathrm{ng}$ of DNA is available, only a fraction of it should be used as too much DNA can result in sample overloading and reduced yield. Since the yields of ChIP DNA experiments vary greatly depending on multiple factors (antibody specificity, antibody affinity, ChIP procedures, etc.), ChIP DNA quantity should be determined prior to the polyA tailing reaction with the Quant-iT ${ }^{\mathrm{TM}}$ PicoGreen dsDNA Reagent Kit. Depending on the hybridization mixture volume used, the processed ChIP material is sufficient for loading 1-15 channels of a flow cell. Yield is typically 7-12 $\mathrm{M}$ aligned reads per channel. End-repair of ChIP DNA may be performed, but has a variable and marginal impact on yield for most samples. Nevertheless, end-repair must be performed on ChIP DNA fragmented using micrococcal nuclease treatment, as this enzyme leaves $3^{\prime}$ phosphate groups that prevent tailing with terminal transferase, or fragmentation methods leaving high fraction of untailable/blocked 3 ' ends.

\section{Acknowledgements}

The author thanks all past and previous Helicos employees for their help and contribution to the development of the technology and the work described here. This work was partly supported by NHGRI grants R01 HG005230 and R44 HG005279.

\section{References}

Bentley, D.R., Balasubramanian, S., Swerdlow, H.P., Smith, G.P., Milton, J., Brown, C.G., Hall, K.P., Evers, D.J., Barnes, C.L., Bignell, H.R., et al. (2008). Accurate whole human genome sequencing using reversible terminator chemistry. Nature 456, 53-59.

Bowers, J., Mitchell, J., Beer, E., Buzby, P.R., Causey, M., Efcavitch, J.W., Jarosz, M., Krzymanska-Olejnik, E., Kung, L., Lipson, D., et al. (2009). Virtual terminator nucleotides for next-generation DNA sequencing. Nat. Methods 6, 593-595.

Giladi, E., Healy, J., Myers, G., Hart, C., Kapranov, P., Lipson, D., Roels, S., Thayer, E., and Letovsky, S. (2010). Error tolerant indexing and alignment of short reads with covering template families. J. Comput. Biol. 17, 1397-1411.

Goren, A., Ozsolak, F., Shoresh, N., Ku, M., Adli, M., Hart, C., Gymrek, M., Zuk, O., Regev, A., Milos, P.M., et al. (2010). Chromatin profiling by directly sequencing small quantities of immunoprecipitated DNA. Nat. Methods 7, 47-49.

Harris, T.D., Buzby, P.R., Babcock, H., Beer, E., Bowers, J., Braslavsky, I., Causey, M., Colonell, J., Dimeo, J., Efcavitch, J.W., et al. (2008). Single-molecule DNA sequencing of a viral genome. Science 320, 106-109.

Kapranov, P., Ozsolak, F., Kim, S.W., Foissac, S., Lipson, D., Hart, C., Roels, S., Borel, C., Antonarakis, S.E., Monaghan, A.P., et al. (2010). New class of gene-terminiassociated human RNAs suggests a novel RNA copying mechanism. Nature 466, 642-646.

Mardis, E.R. (2008). The impact of next-generation sequencing technology on genetics. Trends Genet. 24, 133-141.

Margulies, M., Egholm, M., Altman, W.E., Attiya, S., Bader, J.S., Bemben, L.A., Berka, J., Braverman, M.S., Chen, Y.J., Chen, Z., et al. (2005). Genome sequencing in microfabricated high-density picolitre reactors. Nature 437, 376-380. 
Morozova, O., and Marra, M.A. (2008). Applications of next-generation sequencing technologies in functional genomics. Genomics 92, 255-264.

Nutiu, R., Friedman, R.C., Luo, S., Khrebtukova, I., Silva, D., Li, R., Zhang, L., Schroth, G.P., and Burge, C.B. (2011). Direct measurement of DNA affinity landscapes on a high-throughput sequencing instrument. Nat. Biotechnol. 29, 659-664.

van den Oever, J.M., Balkassmi, S., Verweij, E.J., van Iterson, M., Adama van Scheltema, P.N., Oepkes, D., van Lith, J.M., Hoffer, M.J., den Dunnen, J.T., Bakker, E., et al. (2012). Single molecule sequencing of free DNA from maternal plasma for noninvasive trisomy 21 detection. Clin. Chem. 58, 699-706.

Orlando, L., Ginolhac, A., Raghavan, M., Vilstrup, J., Rasmussen, M., Magnussen, K., Steinmann, K.E., Kapranov, P., Thompson, J.F., Zazula, G., et al. (2011). True single-molecule DNA sequencing of a pleistocene horse bone. Genome Res. 21, 1705-1719.

Ozsolak, F. (2012). Third-generation sequencing techniques and applications to drug discovery. Expert Opin. Drug Discov. 7, 231-243.

Ozsolak, F., Kapranov, P., Foissac, S., Kim, S.W., Fishilevich, E., Monaghan, A.P., John, B., and Milos, P.M. (2010a). Comprehensive polyadenylation site maps in yeast and human reveal pervasive alternative polyadenylation. Cell 143, 1018-1029.

Ozsolak, F., and Milos, P.M. (2011). RNA sequencing: advances, challenges and opportunities. Nat. Rev. 12, 87-98.

Ozsolak, F., Platt, A.R., Jones, D.R., Reifenberger, J.G., Sass, L.E., Mclnerney, P., Thompson, J.F., Bowers, J., Jarosz, M., and Milos, P.M. (2009). Direct RNA sequencing. Nature 461, 814-818.

Ozsolak, F., Ting, D.T., Wittner, B.S., Brannigan, B.W., Paul, S., Bardeesy, N., Ramaswamy, S., Milos, P.M., and Haber, D.A. (2010b). Amplification-free digital gene expression profiling from minute cell quantities. Nat. Methods 7, 619-621.

Rumble, S.M., Lacroute, P., Dalca, A.V., Fiume, M., Sidow, A., and Brudno, M. (2009). SHRiMP: accurate mapping of short color-space reads. PLoS computational biology 5, e1000386.

Sanger, F., and Coulson, A.R. (1975). A rapid method for determining sequences in DNA by primed synthesis with DNA polymerase. J. Mol. Biol. 94, 441-448.

Tessler, L.A., Reifenberger, J.G., and Mitra, R.D. (2009). Protein quantification in complex mixtures by solid phase single-molecule counting. Anal. Chem. 81, 7141-7148.

Thompson, J.F., Reifenberger, J.G., Giladi, E., Kerouac, K., Gill, J., Hansen, E., Kahvejian, A., Kapranov, P., Knope, T., Lipson, D., et al. (2012). Single-step capture and sequencing of natural DNA for detection of BRCA1 mutations. Genome Res. 22, 340-345.

Valouev, A., Ichikawa, J., Tonthat, T., Stuart, J., Ranade, S., Peckham, H., Zeng, K., Malek, J.A., Costa, G., McKernan, K., et al. (2008). A high-resolution, nucleosome position map of C. elegans reveals a lack of universal sequence-dictated positioning. Genome Res. 18, 1051-1063.

Yu, M., Ting, D.T., Stott, S.L., Wittner, B.S., Ozsolak, F., Paul, S., Ciciliano, J.C., Smas, M.E., Winokur, D., Gilman, A.J., et al. (2012). RNA sequencing of pancreatic circulating tumour cells implicates WNT signalling in metastasis. Nature 487, 510-513.

\section{Other Publications of Interest}

Xu, J-P. (2014). Next-generation Sequencing: Current Technologies and Applications. Caister Academic Press, UK. ISBN: 978-1-908230-33-1

Poptsova, M.S. (2014). Genome Analysis: Current Procedures and Applications. Caister Academic Press, UK. ISBN: 978-1-908230-29-4

He, Z. (2014) Microarrays: Current Technology, Innovations and Applications. Caister Academic Press, UK. ISBN: 978-1-908230-49-2

Saunders, N.A. and Lee, M.A. (2013) Real-Time PCR: Advanced Technologies and Applications. Caister Academic Press, UK. ISBN: 978-1-908230-22-5

Herold, K.E. and Rasooly, A. (2009). Lab-on-a-Chip Technology: Fabrication and Microfluidics. Caister Academic Press, UK. ISBN: 978-1-904455-46-2 


\section{Microbiology / Molecular Biology}

Caister Academic Press is a leading academic publisher of advanced texts in microbiology, molecular biology and medical research. Full details of all our publications at caister.com

- Cyanobacteria: Omics and Manipulation Edited by: DA Los (2017) www.caister.com/cyano3

- Brain-eating Amoebae: Biology and Pathogenesis of Naegleria fowleri

Author: R Siddiqui, IKM Ali, JR Cope, et al. (2016)

"explains the current knowledge and research" (ProtoView) www.caister.com/naegleria

- Foot and Mouth Disease Virus: Current Research and Emerging Trends

Edited by: F Sobrino, E Domingo (2017)

www.caister.com/fmdv

- Staphylococcus: Genetics and Physiology

Edited by: GA Somerville (2016)

www.caister.com/staph2

- Chloroplasts: Current Research and Future Trends Edited by: H Kirchhoff (2016)

www.caister.com/chloroplasts

- Microbial Biodegradation: From Omics to Function and Application

Edited by: J Długoński (2016)

www.caister.com/biodegradation

- Influenza: Current Research

Edited by: Q Wang, YJ Tao (2016)

www.caister.com/flu3

- MALDI-TOF Mass Spectrometry in Microbiology Edited by: M Kostrzewa, S Schubert (2016)

www.caister.com/malditof

- Aspergillus and Penicillium in the Post-genomic Era Edited by: RP Vries, IB Gelber, MR Andersen (2016)

"new and well-presented book" (IMA Fungus)

www.caister.com/aspergillus2

- The Bacteriocins: Current Knowledge and Future

Prospects

Edited by: RL Dorit, SM Roy, MA Riley (2016)

www.caister.com/bacteriocins

- Omics in Plant Disease Resistance

Edited by: V Bhadauria (2016)

"essential reading ... highly recommended" (Biotechnol. Agron.

Soc. Environ.)

www.caister.com/opdr

- Acidophiles: Life in Extremely Acidic Environments

Edited by: R Quatrini, DB Johnson (2016)

"Contributors from a wide range of biological and environmental sciences" (ProtoView)

www.caister.com/acidophiles
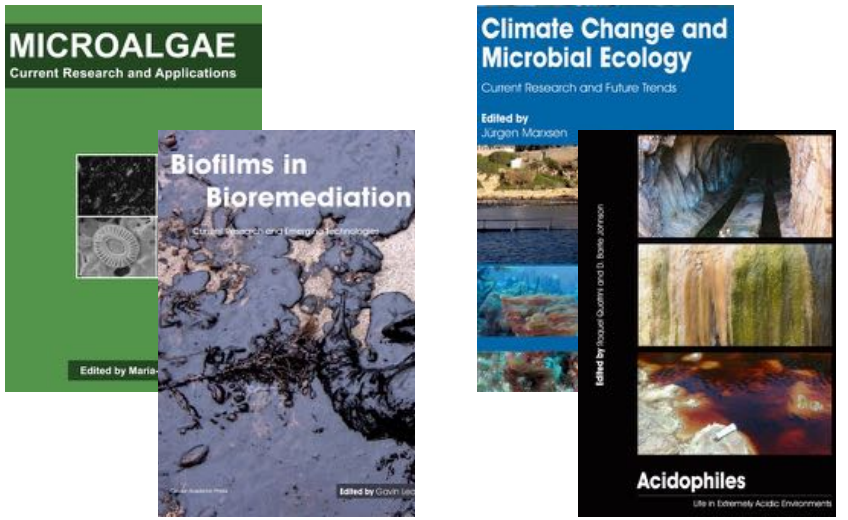
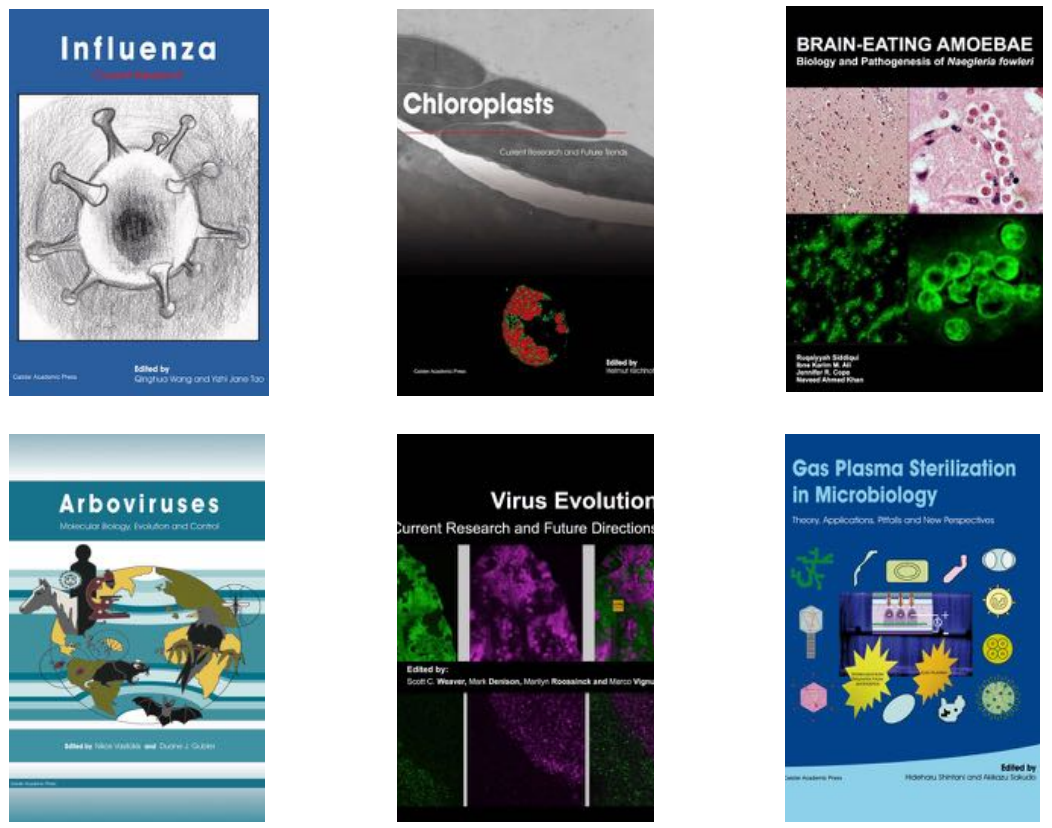

- Climate Change and Microbial Ecology: Current Research and Future Trends

Edited by: J Marxsen (2016)

"impressive" (ASM: Small Things Considered); "written at a high scientific level" (BioSpektrum)

www.caister.com/climate

- Biofilms in Bioremediation: Current Research and Emerging Technologies

Edited by: G Lear (2016)

"describes explicitly the role of biofilms in bioremediation" (Biospektrum); indispensable ... recommended (Biotechnol. Agron. Soc. Environ.) www.caister.com/biorem

- Microalgae: Current Research and Applications

Edited by: MN Tsaloglou (2016)

www.caister.com/microalgae

- Gas Plasma Sterilization in Microbiology: Theory, Applications, Pitfalls and New Perspectives

Edited by: H Shintani, A Sakudo (2016)

"a nice state of the art compilation" (Doodys)

www.caister.com/gasplasma

- Virus Evolution: Current Research and Future Directions Edited by: SC Weaver, M Denison, M Roossinck, et al. (2016) "highly informative ... a pleasure to read" (Microbiol. Today) www.caister.com/virusevol

- Arboviruses: Molecular Biology, Evolution and Control Edited by: N Vasilakis, DJ Gubler (2016)

"a thorough and compelling review ... an outstanding book ... highly recommended" (Am. J. Trop. Med. Hyg.) www.caister.com/arbo

- Shigella: Molecular and Cellular Biology

Edited by: WD Picking, WL Picking (2016)

www.caister.com/shigella

- Aquatic Biofilms: Ecology, Water Quality and Wastewater Treatment

Edited by: AM Romaní, H Guasch, MD Balaguer (2016)

"essential reference book" (Biotechnol. Agron. Soc. Environ.)

www.caister.com/aquaticbiofilms

- Alphaviruses: Current Biology

Edited by: S Mahalingam, L Herrero, B Herring (2016)

"up-to-date review of the field" (Aus. Vet. J.)

www.caister.com/alpha 